\title{
A New Classification Scheme of Fluorite Deposits
}

\author{
Rajni Magotra, Stanzin Namga, Pawan Singh, Neha Arora, P.K. Srivastava* \\ Economic Geology Research Group, Department of Geology, University of Jammu, Jammu, India \\ Email: *pankajsrivastava.ju@gmail.com
}

How to cite this paper: Magotra, R., Namga, S., Singh, P., Arora, N. and Srivastava, P.K. (2017) A New Classification Scheme of Fluorite Deposits. International Journal of Geosciences, 8, 599-610. https://doi.org/10.4236/ijg.2017.84032

Received: March 29, 2017

Accepted: April 25, 2017

Published: April 28, 2017

Copyright $\odot 2017$ by authors and Scientific Research Publishing Inc. This work is licensed under the Creative Commons Attribution International License (CC BY 4.0).

http://creativecommons.org/licenses/by/4.0/ (c) (i) Open Access

\begin{abstract}
Fluorite deposits occur in a variety of geologic environments throughout the globe. It may occur as the main or only economically recoverable ore mineral in deposits or may present as the accessory gangue minerals with other ores. It is therefore necessary to understand various genetic types of the fluorite deposit. The present paper synthesises the information of some of the known fluorite mineralisation from the world so that an understanding of them can help in establishing reliable criteria for further search of fluorite deposit. On the basis of a combination of geological background information and fluorite geochemistry, a new classification scheme is proposed.
\end{abstract}

\section{Keywords}

Fluorite, Classification, Genetic Types, REE Characteristics

\section{Introduction}

Fluorite $\left(\mathrm{CaF}_{2}\right)$, also commercially known as fluorspar, is an important industrial mineral that is used as a raw material in the metallurgical, ceramic and chemical industries apart from optical and lapidary uses. Fluorite belongs to the isometric system, with a cubic, face-centred lattice. It commonly forms octahedrons or cubes, less commonly dodecahedrons and rarely tetrahexahedrons, trapezohedrons, trisoctahedrons, hexoctahedrons and botyroidal forms. It often shows fluorescence, a phenomenon which has derived its name from the mineral itself and not the other way round as is commonly perceived. Fluorite comes in a wide range of colours and has consequently been dubbed "The most colourful mineral in the world". Every colour of the rainbow in various shades is represented by fluorite samples, along with white, black and colourless crystals. Purple, green and yellow are the most commonly found coloured crystals. The causes adding to the colour of fluorite are manifold and run from crystal defects to the trace 
element contents. Several authors have emphasized that coloration cannot be understood only as a stand-alone feature unique to a certain variety of fluorite but as an integral part of geological and mineralogical evolution of the fluorite mineralisation, linking the colour of fluorite with the structure of fluorite ore. It has been established that the physico-chemical environment of fluorite formation represents an important control on the real structural properties of natural fluorite and, therefore, ultimately dictates the color of this mineral [1] [2] [3].

Typical fluorite deposits are massive or form layered crusts, globular and botyroidal aggregates or comb textures. Fluorite also show a variety of replacement textures, fill hairline fractures, exist as disseminations within the host rock or found intergrown with a variety of gangue minerals, such as calcite, quartz and barite. Sulphide minerals such as pyrite, galena and sphalerite may also be present. The identities and the proportions of these other minerals, and the ease with which they can be separated from the fluorite, are important determinants of the viability for individual deposits. Origin of the individual fluorite deposit based on fluid inclusion and geochemistry has been carried out by a number of workers [4] [5] [6].

In the last few years, geoscientists all around the world have paid more attention to the metalliferous deposits in general and strategic minerals in particular. The non-metals, on the other hand, continue to be ignored, considering their enormous resource base in the world and have received less attention and as such fallen out of attraction with mineralogists as well as economic geologists. A rapid decrease in fluorspar production has been recorded and can also be attributed to the restrictions on the use of fluorocarbons (particularly CFCs) in refrigerant gases, aerosol propellants and foam blowing agents related to the Montreal Protocol [7]. Still it is much in demand for other industries and hence had a global annual production to the tune of 6.25 million tones [8]. Some countries like Russia and China are increasing its production to meet the demands. In view of its presence in the varied geologic environment different authors have tried to classify it into various genetic types. None of these classifications however take account of all the deposits present in the world. It is therefore necessary to understand various genetic associations of the fluorite deposit and hence to classify it into various genetic types for the better understanding of the deposits and for future exploration plans.

An endeavour is made in this paper to evaluate the available information from known fluorite mineralisation throughout the globe in order to classify fluorite deposits into different genetic types based upon their geochemical characteristics.

\section{Geologic Environment of Fluorite Deposits}

Fluorite deposits occur throughout the world (Figure 1) in a variety of geologic environments and types of deposits. Fluorite occurs as the main or the only economically recoverable ore mineral in deposits like Las Cuevas, Encantada 


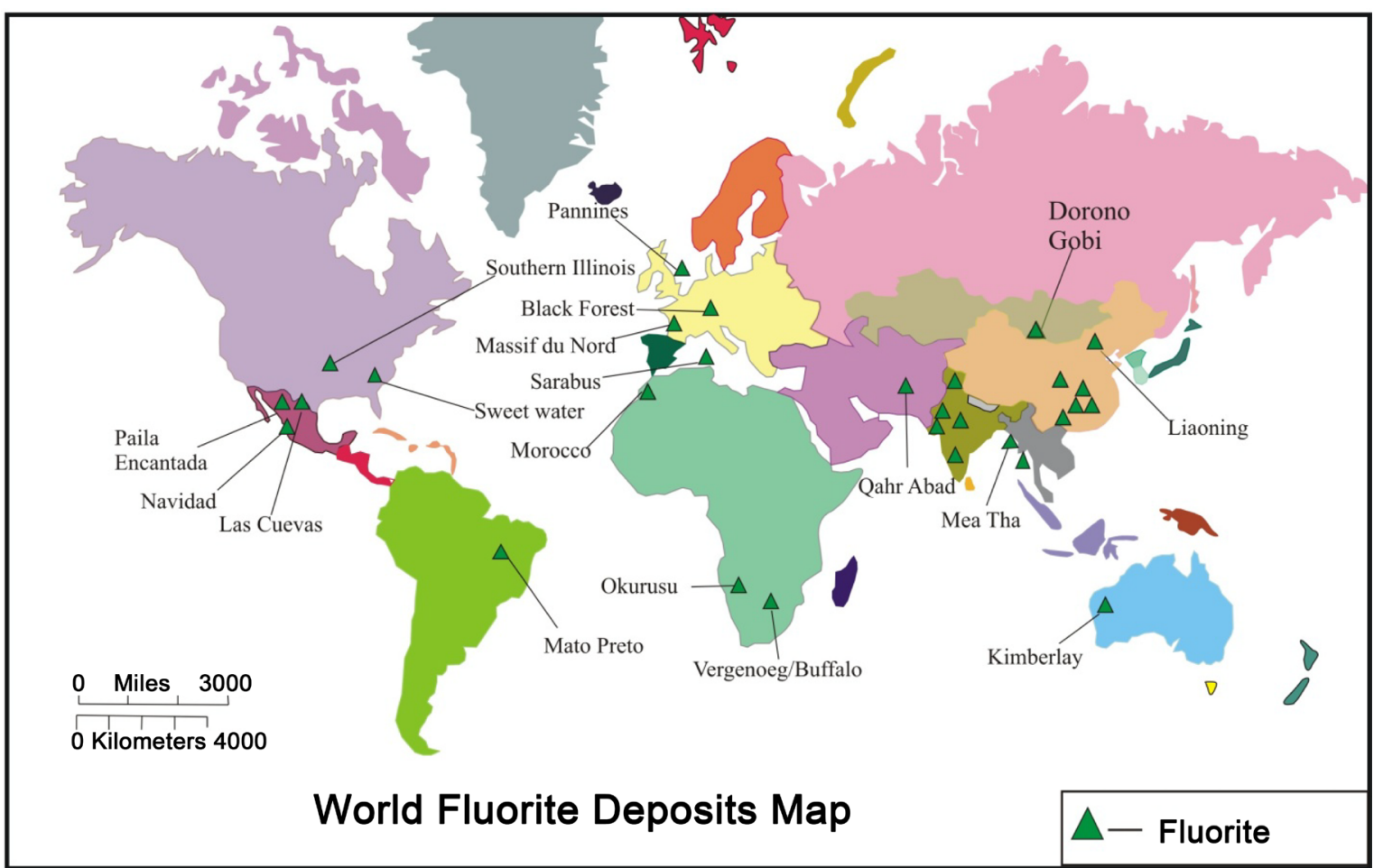

Figure 1. World's fluorite deposits.

Buenavista, El Triangulo (Mexico); St. Lawrence pluton-related veins and the Rock Candy Mine (Canada); El Hamman veins (Morocco); Le Burc, MontrocLe Moulinal and Trebas deposits (France) and Amba Dongar (India) and hence the origin of these deposits has been discussed [9] [10] [11]. However, in many cases, being the accessory gangue mineral associated with the other major ore deposits and also due to the lack of bedrock exposure and laboratory work, the exact nature of the origin of fluorite has not been worked out by the economic geologists. Fluorite mineralisation is commonly associated with carbonatites and alkaline complexes, Mississippi Valley-type $\mathrm{Pb}-\mathrm{Zn}-\mathrm{F}-\mathrm{Ba}$ deposits, F-Ba-(Pb-Zn) veins, hydrothermal $\mathrm{Fe}( \pm \mathrm{Au}, \pm \mathrm{Cu})$ and $\mathrm{REE}$ deposits, precious metal concentrations, fluorite/metal-bearing skarns, Sn-polymetallic greissen-type deposits, zeolitic rocks and uranium deposits [5] [12] [13] [14] [15].

Epigenetic fluorite deposits commonly coincide with regions of low gravity and zones of high heat flow, igneous activity, and hydrothermal effects [16]. Tectonic environments consist chiefly of tensional and deep-seated normal fault zones. The fluorite deposits in the world most commonly occur as veins; mantos (bedded layers, stratabound, or stratiform); pipe like bodies (including mineralized diatremes and cryptovolcanic structures) and stockworks; contact zones and greisens; pegmatites and carbonatites; disseminated deposits in granites, syenites, volcanic rocks, and tuffaceous lake beds. Highly silicic and alkaline igneous rocks are common associates of fluorspar deposits, but any type of rock may act as the host for the actual deposit; limestone and dolomite are most favorable. Most large concentrations of fluorite are associated with continental rifts and lineaments throughout the world [17]. 


\section{Classification Schemes}

A few researchers have tried to classify the fluorite deposits into different categories [4] [18] [19]. A brief review of different classification schemes are given here.

Strong et al. [4] have classified fluorite deposits into two genetic types as : (a) those associated with sedimentary, dominantly carbonate, rocks, and similar in many respects to Mississippi Valley type deposits; and (b) vein-type deposits related to felsic alkaline-peralkaline rocks. They have, however, not considered the deposits associated with carbonatites and also the other occurrences where fluorite occurs as accessory minerals.

While describing fluorite deposit, Korytov [18] suggested that the fluorite deposit may be divided into two broad genetic classes as single stage and multistage deposit. He further classified single stage into magmatic, pegmatite, carbonatite, kimberlite, greisen, skarns, porphyry, sulfide-ore, hydrothermal, metamorphic, and residual types. While the multistage deposits were formed due to two or more single stage processes usually of different ages. Apart from these, Korytov included some new genetic types of fluorite deposits which include hydrothermal sedimentary, hydrothermal (exhalation)-biogenic-sedimentary, mineralized salt and salt-dome, and metamorphogenic-hydrothermal deposits. This classification is complicated one and requires understanding processes involved in the genesis of the deposit before classifying the deposit.

Pohl [19] while classifying different fluorite deposit emphasized that the formation of fluorite deposit is mainly a consequence of magmatic and hydrothermal diagenetic systems. He classified the fluorite deposit into three broad categories as: a) magmatic-hydrothermal fluorite deposits, b) diagenetic-hydrothermal fluorite deposits, c) hydrothermal veins and hydrothermal-metasomatic deposits. This classification seems to be more reliable as it takes into account various types of fluid responsible for the fluorite mineralization.

Association of fluorite with different rock types in diverse geological environments shows variable REE distribution pattern within fluorite which provide insight into the REE proportions in the ore forming fluids and it is of great significance for deciphering the formation conditions of the fluorite deposits [20]. The REE in the fluorite therefore may be used as the genetic indicators for the fluorite as is discussed in the present study.

Keeping in view all the above classification schemes, we propose to classify all the fluorite deposit in three categories based upon their lithological association as: (a) fluorite deposits associated with felsic igneous rocks; (b) fluorite deposits associated with carbonatites and alkaline igneous rocks; and (c) fluorite deposits associated with carbonate and other rocks. The characteristics of these three categories are discussed below.

\subsection{Fluorite Deposit Associated with Felsic Igneous Rocks}

Fluorine bearing igneous rocks are hypabyssal bodies, extrusive igneous rocks (generally of alkalic or silicic-alkalic composition) and plutonic rocks of silicic 
composition. Fluorite is a common constituent of the batholithic rocks of granitic composition. In many parts of the world the granitoids are found genetically associated with fluorite deposits e.g. St. Lawrance deposits (Newfoundland); Bushveld granite fluorite deposits (South Africa); Manto fluorite deposit (Mexico); Rio dos Bugres fluorite mine (Brazil); and Chowkri-Chhapoli deposit, Balda deposit and Kalpatta deposit (India). At places fluorite deposits are also present with the pegmatite (Chumathang, India). Fluorite mineralization of this category mostly occurs as pockets, veins, and disseminations within these rocks or also sometimes within the country rocks. Veins of fluorite of different colours (white, green, violet and dark violet) vary from fraction of an inch to few inches in width. Fluorite occurs as cubes of white, purple and green colours with octahedral cleavage that have been emplaced along prominent shears and fractures traversing the rocks.

The fluid inclusion data of the fluorite of this type indicate that these deposits normally show homogenization temperature ranging between $80^{\circ} \mathrm{C}$ to $280^{\circ} \mathrm{C}$ and rarely goes above $300^{\circ} \mathrm{C}$. The salinity of the inclusions within the fluorite of this category widely ranges between $0.18 \mathrm{wt} \%$ eq $\mathrm{NaCl}$ to $21.0 \mathrm{wt} \%$ eq $\mathrm{NaCl}$ [21] [22].

REE's in fluorite associated with felsic rocks vary from deposit to deposit. In general, these fluorites are enriched in intermediate to HREEs than LREEs. Yttrium in such fluorites is also anomalously enriched and show strong positive anomaly. The chondrite normalised REEs of the fluorite associated with granite and other felsic rocks from different deposits of the world are plotted in (Figure 2). These fluorites show a typical relatively flat trend with a prominent negative $\mathrm{Eu}$ anomaly. It is suggested that such fluorite show similar REE trends as of the associated granite [4]. Some changes in the pattern is due to late phases of fluorite. Distinct compositional differences exist between early and late formed fluorite within the hydrothermal fluorites [23].

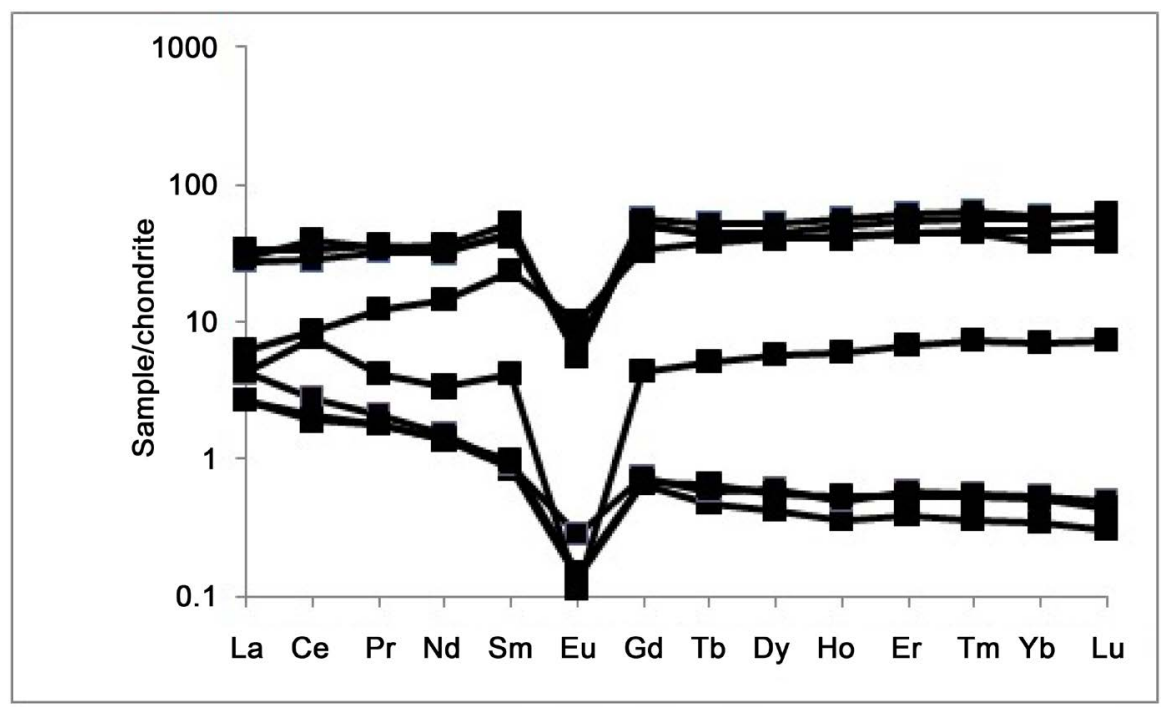

Figure 2. REE distribution pattern for fluorite associated with felsic magmatism. All samples are normalised by chondrites [24]. Data Source: [25] [26] [27]. 


\subsection{Fluorite Deposits Associated with Carbonatites}

Some of the largest producing deposits of fluorite are associated with carbonatites and located at Okorusu (Namibia), Amba dongar (India), and MatoPreto (Brazil). The association between carbonatite and fluorite is well recognized [28] [29]. Economic fluorite deposits associated with carbonatite complexes are contact and late stage hydrothermal deposits. Dean and Powell [30] suggested that deposition of fluorite in the carbonatites of Tororo, Uganda and Chilwa Island, Malawi in Africa were associated with late stage emanations from the carbonatitic magma. Some late stage carbonatite hosted fluorite deposits were also interpretated through fluid inclusion data which shows its deposition from hydrothermal solutions that evolved from magma chamber which produce carbonatite intrusions [31]. Theory of the mixing of magmatic fluorine-rich fluids with calcium-rich formation water in the sedimentary country rocks giving rise to carbonatite associated deposits have also been proposed by different workers [29] [30]. In such deposits numerous veins of fluorite with barite, chalcopyrite, dickite, galena and pyrite occur at the contact of carbonatite with fenitized sedimentary rocks. Fluorite veins in many areas are also found confined to large faults and subordinate fissures of deep seated regional tensional nature, as in India [32] in eastern Mongolia [33] United States [34] and along the rift valleys of Africa.

The fluid inclusion data of the fluorite of this type indicate that these deposits normally show homogenization temperature mostly ranging between $95^{\circ} \mathrm{C}$ to $440^{\circ} \mathrm{C}$. The salinity of the inclusions within the fluorite of this category widely ranges between $0.87 \mathrm{wt} \%$ eq $\mathrm{NaCl}$ to $11 \mathrm{wt} \%$ eq $\mathrm{NaCl}$ [35].

The fluorites associated with carbonatites and other alkaline magmatism is found enriched in LREE concentration particularly in Ce, Pr and $\mathrm{Nd}$ than the HREE with lack of negative Eu anomaly (Figure 3). The slight enrichment of the intermediate REE's gives a convex up pattern for the chondrite normalized REE

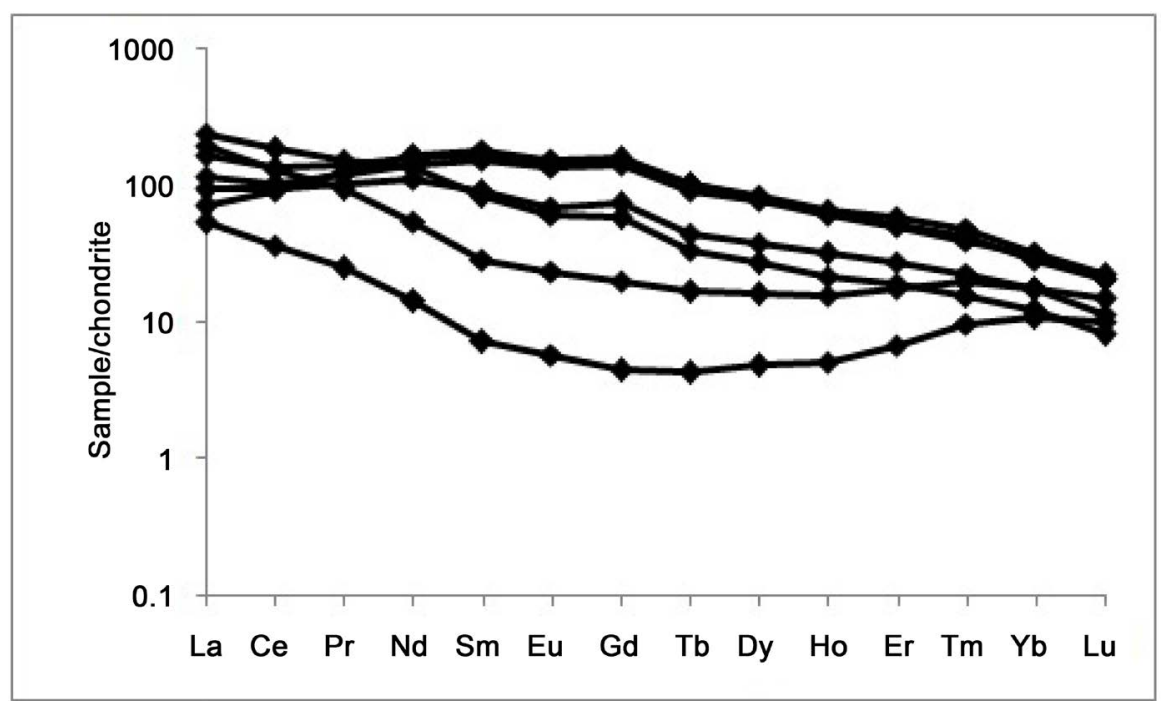

Figure 3. Chondrite normalised REE distribution pattern for fluorite associated with Carbonatite and alkali igneous rocks. Data Source: [22] [36]. 
of the fluorite associated with carbonatite and alkaline igneous rocks. Yttrium in these fluorite also show positive anomaly.

\subsection{Fluorite Associated with Sedimentary Rocks and MVT Deposit}

These types of epigenetic fluorite deposits are very common and are suggested to be formed by the digenetic fluids. These deposits are characterised by very low temperature of formation $\left(100^{\circ} \mathrm{C}-150^{\circ} \mathrm{C}\right.$ and mostly occur as open space fillings, collapse and solution breccias and/or replacement within the carbonate and sedimentary host rock.

Fluorite mineralization of hydrothermal origin in limestone occurs when temperature conditions are suitable for the crystallization of fluorite. The hot water highly enriched in fluorine with dissolved chemicals deep under the earth rises towards the surface over the time period. Fluorite deposit of Illinois is of this type where the water flowed through northeast-trending faults and fractures in limestones laid down in the Mississippian period, about 330 million years ago. When the hot brines reached the calcium-rich Mississippian rocks, the temperature and other conditions were just right for crystallizing fluorite along the walls of the faults and in flat-lying parallel to the beds of limestone. These host rocks dissolved and were replaced with fluorite. Fluorite deposit associated with sedimentary rocks includes deposits at Jabalpur district, Madhya Pradesh (India), Pennines deposits (England), La azul deposit in Taxco district, Purisima Mine, Coahuila, (Mexico), eastern Harz Mountains (Germany), Northwestern Sicily.

The fluid inclusion data of the fluorite of this type indicate that these deposits normally show homogenization temperature mostly ranging between $100^{\circ} \mathrm{C}$ to $150^{\circ} \mathrm{C}$. The salinity of the inclusions within the fluorite of this category widely ranges between $12 \mathrm{wt} \%$ eq $\mathrm{NaCl}$ to $22 \mathrm{wt} \%$ eq $\mathrm{NaCl}$ [6] [37] [38].

The REE content of the fluorite associated with carbonate sedimentary rocks show varied concentration. Overall it has much lower concentration of LREEs than the fluorite associated with magmatic rocks with slight negative Ce anomaly. HREE's in fluorite hosted in sedimentary rocks shows a moderate to low negative anomaly for $\mathrm{Yb}$. One sample of MVT shows low concentration of LREE'S and depleted in HREE's (Figure 4).

\section{Discussion and Conclusions}

Fluorine is considered as a characteristic component of the volatile phase during magmatic differentiation. As such the concentration of fluorite in the residual solutions resulting from the magmatic processes is due to the fact that the crystallizing mineral phases do not incorporate appreciable amounts of fluorine as a main constituent and also the greater solubility of HF than water in silicate melts lowers the melting temperature. The ideal conditions for the precipitation of fluorite are provided when the fluorine in the form of the complex $\mathrm{SiF}_{6}^{-2}$ come in contact with adequate number of $\mathrm{Ca}^{2+}$ ions, provided by calcium carbonate bearing host rock, at the cooling below $200^{\circ} \mathrm{C}$ [39]. Fluorine-rich high-silica 


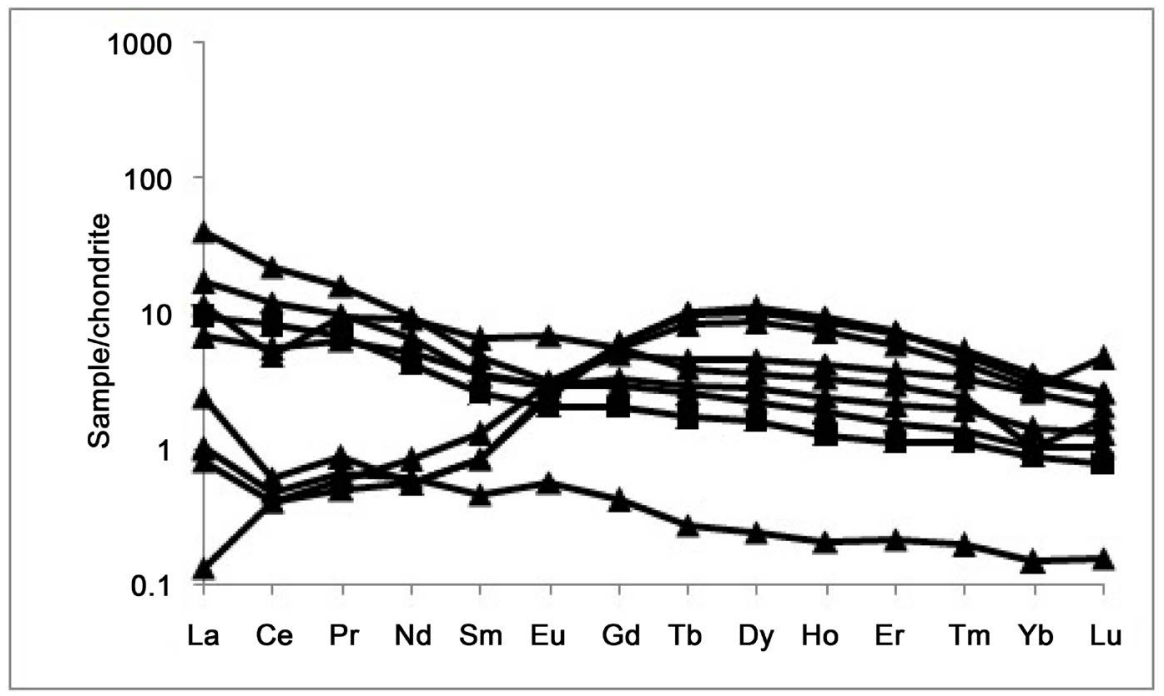

Figure 4. Chondrite normalised REE distribution pattern in fluorite related with sedimentary rocks. (Data Source: [38] [40] [41] [42] [43].

magma and their corresponding A-type granites and rhyolite have fluorite as a characteristic accessory phase which is believed to precipitate during magmatic and or magmatic-hydrothermal stages [44] [45] [46] [47]. It has been suggested that the MVT fluorite ores are resulted from the replacement of carbonate rocks after they underwent an epigenetic dolomitization [38]. Three mechanisms for the deposition of fluorite: 1) decrease in temperature and/or pressure, 2) fluid mixing, and 3) interaction of the hydrothermal fluid with the wall rocks have been suggested [48].

It is well known that fluorite may concentrate REE from the melt or fluid from which it crystallizes. Many workers have used the REE content of fluorite associated with magmatic rocks to understand magmatic to magmatic-hydrothermal processes as REE and Sr substitute for Ca in fluorite [49] [50] [51]. Despite the relatively abundant petrological data on fluorine-rich high-silica rhyolites and granites, the stability conditions and genesis of the accessory fluorite associated with such rocks are poorly constrained. The main question concerning the fluorite formation within evolved high-silica rhyolites and granites is whether it formed under supersolidus conditions from a silicate melt or from a magmatic-hydrothermal fluid, or under subsolidus conditions from a postmagmatic fluid [47].

Using the REE data of fluorite deposits hosted in different rock types the chondrite normalised diagrams (Figures 2-4) have been constructed to find out the variation in REE trend between different genetic types of fluorite deposits associated with different geological environments. The fluorite associated with diagenetic process (sedimentary rocks) shows very low concentration of REEs than the fluorite associated with the magmatic rock (felsic igneous rock and carbonatite and other alkali igneous rocks). The fluorite formed due to felsic magmatism is further differentiated from the fluorite formed due to the carbonatitic and alkali melts by its strong Eu anomaly. The fluorite associated with 
Table 1. New Classification scheme for fluorite deposit.

\begin{tabular}{lll}
\hline \multicolumn{1}{c}{ Type of fluorite deposit } & \multicolumn{1}{c}{ Lithological association } & \multicolumn{1}{c}{ Rare earth element content of fluorite } \\
\hline $\begin{array}{l}\text { Fluorite deposit associated } \\
\text { with felsic igneous rocks }\end{array}$ & $\begin{array}{l}\text { Felsic igneous rocks (granitoids and pegmatite) } \\
\text { some time also hosted by surrounding } \\
\text { metamorphic country rocks. }\end{array}$ & $\begin{array}{l}\text { Enriched in intermediate to HREEs than LREEs. Yttrium is } \\
\text { highly enriched and show strong positive anomaly. These } \\
\text { fluorite show a typical relatively flat trend with a prominent } \\
\text { negative Eu anomaly. }\end{array}$ \\
$\begin{array}{l}\text { Fluorite deposit associated } \\
\text { with carbonatite }\end{array}$ & Carbonatite and alkali igneous rocks & $\begin{array}{l}\text { Enriched in LREE concentration than the HREE with lack } \\
\text { of negative Eu anomaly. The slight enrichment of the } \\
\text { intermediate REEs over LREE and HREE give a convex up } \\
\text { pattern for the chondrite normalized REE of the fluorite of } \\
\text { this type. Y show positive anomaly. }\end{array}$ \\
$\begin{array}{l}\text { Fluorite deposit associated } \\
\text { with carbonate sedimentary } \\
\text { rocks }\end{array}$ & Carbonate and other sedimentary rocks & $\begin{array}{l}\text { Overall very low but varying REE concentration. Low to } \\
\text { moderate negative Ce and Yb anomaly. }\end{array}$ \\
\hline
\end{tabular}

felsic igneous rocks are characterised by the strong to moderate negative Eu anomaly and enrichment of LREE over the HREE. While the fluorite associated with carbonatite show lack of Eu anomaly and slight enrichment of the intermediate REEs over the LREEs and HREEs.

Based on the above discussion, we propose a new classification scheme (Table 1) based on lithological association and REE content of the fluorite. It is proposed that the REE concentration of the fluorite minerals can be potentially used to decipher the processes involved in the genesis of the fluorite.

\section{References}

[1] Krasilshchykova, O.A., Platonov, A.N. and Tarashchan, A.N. (1974) On the Colour Centres in Natural Fluorites. Minerals, 28, 31-40. (In Russian)

[2] Bill, H. and Callas, G. (1978) Colour Centers, Associated Rare-Earth Ions and the Origin of Coloration in Natural Fluorites. Physics and Chemistry of Minerals, 3, 117-131. https://doi.org/10.1007/BF00308116

[3] Trinkler, M. (1997) Optically Active Centers in Natural Fluorites and Scheelites and Their Relationships to Chemism and Genesis. Scientific Information, Freiberg.

[4] Strong, D.F., Fryer, B.J. and Kerrich, R. (1984) Genesis of the St. Lawrence Fluorspar Deposits as Indicated by Fluid Inclusion, Rare Earth Element, and Isotopic Data. Economic Geology, 79, 1142-1158. https://doi.org/10.2113/gsecongeo.79https://doi.org/10.2113/gsecongeo.79.5.1142

[5] Alvin, M.P., Dunphy, J.M. and Groves, D.I. (2004) Nature and Genesis of a Carbonatite-Associated Fluorite Deposit at Speewah, East Kimberley Region, Western Australia. Mineralogy and Petrology, 80, 127-153.

[6] Bejaoui, J., Salah, B. and Donatella, B. (2013) Geology, Mineralogy and Fluid Inclusions Investigation of the Fluorite Deposit at Jebel Kohol, Northeastern Tunisia. $\mathrm{Pe}$ riod Mineral, 82, 217-237.

[7] Simandl, G. (2009) World Fluorspar Resources, Market and Deposit Examples from British Columbia, Canada. British Columbia Geological Survey, Information Circular, 209, 1-16.

[8] Ministry of Mines Government of India (2015) Indian Minerals Year Book, Part III. 54th Edition.

[9] Gonzalez, P.E., Carrillo, C.A., Grimmer, J.O.W., Pironon, J., Mutterer, J. and 
Levresse, G. (2003) Fluorite Deposits at Encantada-Buenavista, Mexico, Products of Mississippi Valley Type Process. Ore Geology Reviews, 23, 107-124.

[10] Munoz, M., Wayne, R.P. and Pierre, C.R. (2005) Sm-Nd Dating of Fluorite from the World Class Montroc Fluorite Deposit, Southern Massif Central, France. Mineralium Deposita, 39, 970-975. https://doi.org/10.1007/s00126-004-0453-9

[11] Fulton III, R.B. and Miller, M.M. (2006) Fluorspar in Industrial Minerals and Rocks. In: Kogel, J.E., Eds., Industrial Minerals \& Rocks. Commodities, Markets, and Uses, Society for Mining Metallurgy and Exploration, Englewood, 7th Edition, 461-473.

[12] Xu, C., Zhang, H., Huang, Z., Liu, C., Qi, L., Li, W. and Guan, T. (2004) Genesis of the Carbonatite-Syenite Complex and REE Deposit at Maoniuping, Sichuan Province, China, Evidence from Pb Isotope Geochemistry. Geochemical Journal, 38, 6776. https://doi.org/10.2343/geochemj.38.67

[13] Bettencourt, J.S., Leite Jr., W.B., Goraieb, C.L., Sparrenberger, I., Bello, R.M.S. and Payolla, B.L. (2005) Sn-Polymetallic Greissen-Type Deposits Associated with Late-Stage Rapakivi Granites, Brazil, Fluid Inclusion and Stable Isotope Characteristics. Lithos, 80, 363-386.

[14] Min, M., Fang, C. and Fayek, M. (2005) Petrography and Genetic History of Coffinite and Uraninite from the Liueryiqi Granite-Hosted Uranium Deposit, SE China. Ore Geology Reviews, 26, 187-197.

[15] Levresse, G., Trittla, J., Villareal, J. and Gonzalez., P.E. (2006) The "El Pilote" Fluorite Skarn, A Crucial Deposit in the Understanding and Interpretation of the Origin and Mobilization of Fluorite from Northern Mexico Deposits. Journal of Geochemical Exploration, 89, 205-209.

[16] Shawe, D.R. and John, H.S. (1976) Ore Deposits as Related to Tectonics and Magmatism. Nevada and Utah, Transactions of the American Institute of Mining. Metallurgical, and Petroleum Engineers, 260, 225-232.

[17] Van Alstine, R.E. (1976) Continental Rifts and Lineaments Associated with Major fluorspar Districts. Economic Geology, 71, 977-987. https://doi.org/10.2113/gsecongeo.71.6.977

[18] Korytov, F.Y. (2010) New Types of Fluorite Deposits and Their Genesis. International Geology Review, 28, 1102-1110. https://doi.org/10.1080/00206818609466353

[19] Pohl, W.L. (2011) Economic Geology: Principles and Practice. Willey Blackwell, Oxford, 663. https://doi.org/10.1002/9781444394870

[20] Vinokurov, S.F., Golubev, V.N., Krylova, T.L. and Prokof ev, V.Y. (2014) REE and Fluid Inclusions in Zoned Fluorites from Eastern Transbaikalia, Distribution and Geochemical Significance. Geochemistry International, 52, 654-669. https://doi.org/10.1134/S0016702914060093

[21] Salem, I.A., Abdel-Moneum, A.A., Shazly, A.G. and El-Shibiny, N.H. (2001) Mineralogy and Geochemistry of Gabal El-Ineigi Granite and Associated Fluorite Veins, Central Eastern Desert, Egypt, Application of Fluid Inclusions to Fluorite Genesis. Journal of African Earth Sciences, 32, 29-45.

[22] Buhn, B., Rankin, A.H., Schneider, J. and Dulski, P. (2002) The Nature of Orthomagmatic, Carbonatitic Fluids Precipitating REE, Sr-Rich Fluorite, Fluid-Inclusion Evidence from the Okorusu Fluorite Deposit, Namibia. Chemical Geology, 186, 75-98.

[23] Gagnon, J.E., Samson, I.M., Fryer, B.J. and Williams-Jones, A.E. (2003) Compositional Heterogeneity in Fluorite and the Genesis of Fluorite Deposits, Insights from LA-ICP-MS Analysis. The Canadian Mineralogist, 41, 365-382. https://doi.org/10.2113/gscanmin.41.2.365 
[24] Taylor, S.R. and McLennan, S.M. (1985) The Continental Crust, Its Composition and Evolution. Blackwell, Oxford, 312.

[25] Mohamed, F.H. and Mohamed, M.E. (2008) Post-Orogenic and Anorogenic A-Type Fluorite-Bearing Granitoids, Eastern Desert, Egypt, Petrogenetic and Geotectonic Implications. Chemie der Erde-Geochemistry, 68, 431-450.

[26] Shunda, Y., Jiantang, P., Ruizhong, H.U., Xianwu, B.I., Liang, Q.L., Zhaoli, L.I., Xiaomin, L.I. and Yan, S. (2008) Characteristics of Rare-Earth Elements (REE), Strontium and Neodymium Isotopes in Hydrothermal Fluorites from the Bailashui Tin Deposit in the Furong Ore Field, Southern Hunan Province, China. Geochemical Journal, 27, 342-350.

[27] Mohamed, M.A., Habaak, G.H., Bishara, E.W.W. and Hadek, H.H. (2009) Geochemical and Fluid Inclusions Studies on Fluorite Mineralization at HomrAkarem and HomretMikpid Granites, South Eastern Desert, Egypt. Mansoura Journal of Biology, 36, 227-247.

[28] Woolley, A.R. (1989) The Spatial and Temporal Distribution of Carbonatites. In: Bell, K., Ed., Carbonatites: Genesis and Evolution, Unwin Hyman, London, 15-37.

[29] Palmer, D.A.S. and William-Jones, A.E. (1996) Genesis of the Carbonatite-Hosted Fluorite Deposit at Amba Dongar, India, Evidence from Fluid Inclusions, Stability Isotopes, and Whole Rock-Mineral Geochemistry. Economic Geology, 91, 934-950. https://doi.org/10.2113/gsecongeo.91.5.934

[30] Deans, T. and Powell, J.L. (1968) Trace Elements and Strontium Isotopes in Carbonatites Fluorites, and Limestones from India and Pakistan. Nature, 218, 750-752. https://doi.org/10.1038/218750a0

[31] Puzanov, L.S. (1977) Origin of Fluorite Mineralisation in Carbonatite of the Bolshaya Tagna Pluton, Eastern Sayan. Doklady Akademii Nauk, 233, 463-466.

[32] Deans, T., Sukheswala, R.N., Sethna, S.F. and Viladkar, S.G. (1972) Metasomatic Feldspar Rocks (Potash Fenites) Associated with the Fluoride Deposits and Carbonatites of Ambadongar Gujrat, India. Transactions of the Institution of Mining and Metallurgy, 717, B1-B9.

[33] Khasin, R.A. and Kalenov, A.D. (1965) Distribution Patterns of Fluorite Mineralization in Eastern Mongolia. Doklady Akademii Nauk, 164, 115-117.

[34] Worl, R.G., Van, R.E.A. and Shawe, D.R. (1973) United States Mineral Resources. Geological Survey Professional Paper, 820, 223.

[35] Kozlowski, A., Wiszniewska, J. and Sikorska, M. (2005) Fluid Inclusions and Cathodoluminescence of Fluorite from Carbonatites of the Tajno Massif, NE Poland. Polskie Towarzystwo Mineralogiczne-Prace Specjalne, 26, 40-46.

[36] Rajabzadeh, M.A. (2007) A Fluid Inclusion Study of a Large MVT Barite-Fluorite Deposit, Komshecheh, Central Iran. Iranian Journal of Science and Technology, 31, 73-87.

[37] Xu, C., Taylor, N.R., Wenbe, L., Kynicky, J., Chakhmouradian, R.A. and Song, W. (2012) Comparison of Fluorite Geochemistry from REE Deposits in the Panxi Region and Bayan Obo, China. Journal of Asian Earth Sciences, 57, 76-89.

[38] Souissi, F., Radhia, S. and Dandurand, J.L. (2010) The Mississippi Valley-Type Fluorite Ore at Jebel Stah (Zaghouan District, North-Eastern Tunisia), Contribution of REE and Sr Isotope Geochemistries to the Genetic Model. Ore Geology Reviews, 37, 15-30.

[39] Murty, Y.G.K. (1973) Certain Aspects of the Occurrence of Fluorite in India and Its Exploration. Geological Survey of India, Records, 113, 1-15.

[40] Deng, X.H., Chen, Y.J., Yao, J.M., Bagas, L. and Tang, H.S. (2014) Fluorite REE-Y 
(REY) Geochemistry of the ca. 850Ma Tumen Molybdenite-Fluorite Deposit, Eastern Qinling, China, Constraints on Ore Genesis. Ore Geology Reviews, 63, 532-543.

[41] Sizaret, S., Marcoux, E., Jébrak, M. and Touray, J.C. (2004) The Rossignol Fluorite Vein, Chaillac, France, Multiphase Hydrothermal Activity and Intravein Sedimentation. Economic Geology, 99, 1107-1122. https://doi.org/10.2113/gsecongeo.99.6.1107

[42] Sanchez, V., Cardellach, E., Corbella, M., Vindel, E., Martin-Crespo, T. and Boyce, A.J. (2010) Variability in Fluid Sources in the Fluorite Deposits from Asturias (N Spain), Further Evidences from REE, Radiogenic (Sr, Sm, Nd) and Stable (S, C, O) Isotope Data. Ore Geology Reviews, 37, 87-100.

[43] Alipour, S., Ali, A. and Babak, T. (2015) Geochemical Characteristics of the QahrAbad Fluorite Deposit, Southeast of Saqqez, Western Iran. Arabian Journal of Geosciences, 8, 7309-7320. https://doi.org/10.1007/s12517-014-1747-6

[44] Collins, W.J., Beams, S.D., White, A.J.R. and Chappell, B.W. (1982) Nature and Origin of A-Type Granites with Particular Reference to Southeastern Australia. Contributions to Mineralogy and Petrology, 80, 189-200. https://doi.org/10.1007/BF00374895

[45] Christiansen, E.H., Burt, D.M., Sheridan, M.F. and Wilson, R.T. (1983) The Petrogenesis of Topaz Rhyolites from the Western United States. Mineralogy and Petrology, 83, 16-30. https://doi.org/10.1007/BF00373075

[46] Webster, J.D. and Duffield, W.A. (1994) Extreme Halogen Abundances in Tin-Rich Magma of The Taylor Creek Rhyolite, New Mexico. Economic Geology, 89, 840 850. https://doi.org/10.2113/gsecongeo.89.4.840

[47] Sallet, R., Robert, M. and Denis, F. (2000) Fluorite 87Sr/86Sr and REE Constraints on Fluid-Melt Relations, Crystallization Time Span and Bulk D Sr of Evolved High-Silica Granites. Tabuleiro Granites, Santa Catarina, Brazil. Chemical Geology, $164,81-92$.

[48] Richardson, C.K. and Holland, H.D. (1979) Fluorite Deposition in Hydrothermal Systems. Geochimica et Cosmochimica Acta, 43, 1327-1335.

[49] Mineyev, D.A. (1969) Spectrum of Lanthanoids in Ores of Rare Earth Deposits of Different Genetic Types. International Geology Review, 11, 965-971. https://doi.org/10.1080/00206816909475137

[50] Marchand, L., Joseph, D., Touray, J.C. and Treuil, M. (1976) Criteria for Geochemical Analysis of Fluorite Deposits Based on the Study of the Lanthanide Distribution-Application to the Maine Gite 71-Cordesse, France. Mineralium Deposita, 11, 357-379. https://doi.org/10.1007/BF00203085

[51] Tsareva, G.M., Naumov, V.B., Kovalenko, V.I., Tsepin, A.I. and Babanskiy, A.D. (1992) Melt-Inclusion Data on the Composition and Crystallization Conditions of the Spor Mountain Topaz Rhyolite. Geochemistry International, 29, 93-102. 
Submit or recommend next manuscript to SCIRP and we will provide best service for you:

Accepting pre-submission inquiries through Email, Facebook, LinkedIn, Twitter, etc. A wide selection of journals (inclusive of 9 subjects, more than 200 journals)

Providing 24-hour high-quality service

User-friendly online submission system

Fair and swift peer-review system

Efficient typesetting and proofreading procedure

Display of the result of downloads and visits, as well as the number of cited articles Maximum dissemination of your research work

Submit your manuscript at: http://papersubmission.scirp.org/

Or contact ijg@scirp.org 